\title{
Testing of Selected Phytoindicators for the Environmental Assessment of Areas under Various Levels of Pollution**
}

\section{Introduction}

The problem of the pollution of environment with suspended particles has been very significant over the recent years [14]. Thus better and better ways were sought to monitor the pollutants, which are often transported from large distances e.g. from abroad, which additionally makes their identification more difficult. The composition of suspended particles originating from industrial and urban emission is differentiated, thus their impact on soil and vegetation is various. Trace metals make one of the main elements of suspended particles. Deposition of metals can be measured by many methods; however the majority of them are very expensive and time-consuming, which limits the number of check points. The alternative can be environmental biomonitoring. Its general advantages are: common occurrence of selected groups of organisms in the field, the easiness of sampling, no necessity of using complicated and expensive equipment [13]. The analysis of chemical composition of plants in many aspects shows the advantage compared to traditional studies on soil or water samples. It has been proved that it makes a useful tool at the assessment of environmental quality and management [3]. The best method to measure the content of harmful elements in the environment and the threat they pose to living organisms is the measurement of the concentration of these substances in these organisms [4]. Good indicators of pollution with metals are some species of vascular plants $[2,5,10$, $11,12,15]$, and in particular bryophytes (mosses) [2, 4, 7, 8, 9, 12, 13, 16, 17].

Bryophytes have been described in literature as being able to intercept, retain and accumulate pollutants. They have bioconcentration ability to accumulate metals to levels far above their expected physiological needs. Metal biomonitoring with mosses was first used by Ruling and Tyler in the late 1960s. Survey of heavy metals in

* AGH Univeristy of Science and Technology, Faculty of Mining Surveying and Environmental Engineering, Krakow, Poland

* The study was performed in the Department of Environmental Management and Protection and financed by research project no. 11.11.150.008 
mosses was originally established in 1980 in Sweden [8, 9] and has been used across the whole Europe. It is based on the fact that mosses, especially the carpet - forming species, obtain most of their nutrients from precipitation and dry deposition, so there is little uptake of metals from the substrate. Some trace metals (e.g. $\mathrm{Cu}, \mathrm{Pb}, \mathrm{Zn}$ ) are not very mobile in plants $[1,6]$, thus it is thought that the atmospheric deposition is the main source of these elements in the parts of trees above the ground [5, 10,15].

The aim of this paper was to determine the suitability of six plant species in biomonitoring of pollution from atmospheric trace metal deposition $(\mathrm{Cu}, \mathrm{Cd}, \mathrm{Pb})$.

\section{Material and Methods}

The study area includes three areas in the south of Poland: Krakow agglomeration, Spisz-Gubałów Foothills (Pogórze Spisko-Gubałowskie) and the Silesian Beskid (Beskid Śląski) (Fig. 1). Within these areas four objects were selected for sampling: object 1 - Aleje Trzech Wieszczów (the main avenue near the centre), object 2 - the range of Sowiniec, Object 3 - the stream Jurgowczyk, object 4 - the range of Great Czantoria. The selection criteria includes (among others) factors such as the fact of common occurrence of the selected plant species; differentiation of anthropogenic pressure on a given object: from the areas with no anthropogenic pressure (Spisz-Gubałów Foothills chosen as the reference area), to the object under strong anthropogenic pressure, such as Aleje.

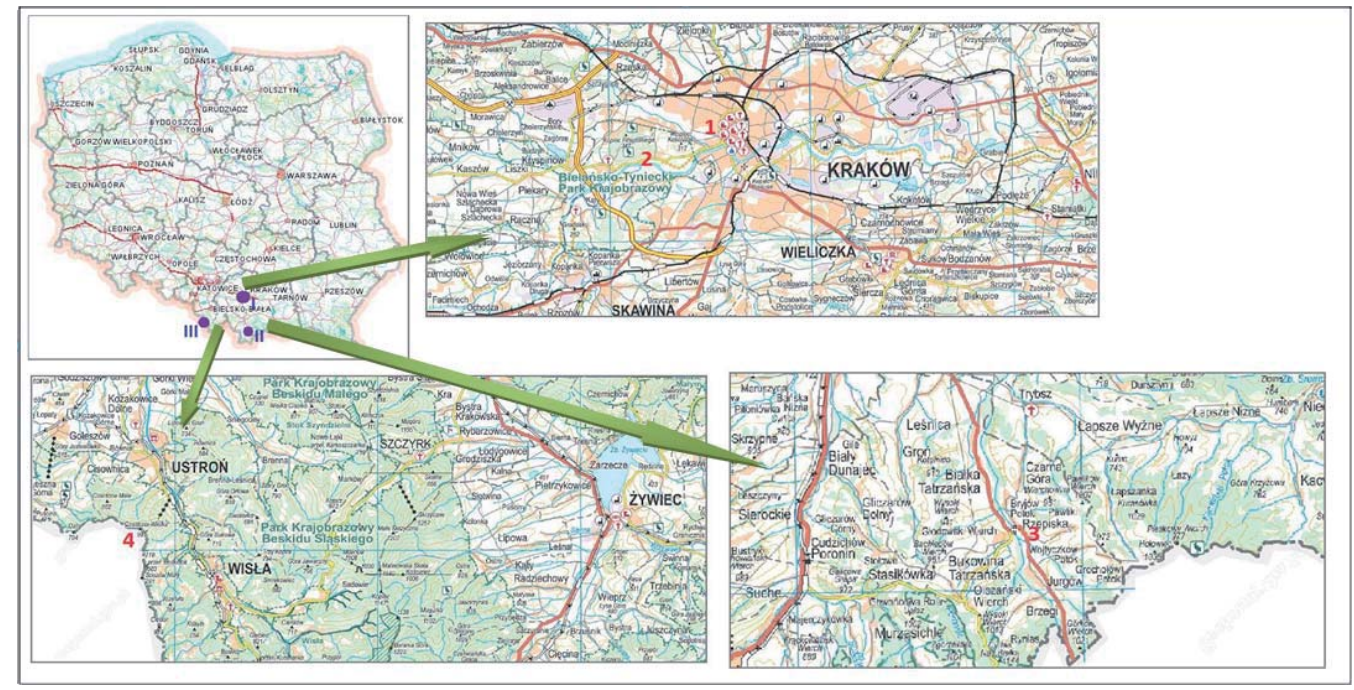

Fig. 1. Location of the sampling sites: I - Krakow Agglomeration: 1 - Aleje Trzech Wieszczów, 2 - Sowiniec Range (pasmo Sowiniec); II - Spisz-Gubałów Foothills (Pogórze Spisko-Gubałowkie): 3 - Jurgowczyk Stream (potok Jurgowczyk) ; III - Silesian Beskid (Beskid

Śląski): 4 - Great Czantoria (Czantoria Wielka)

Source: the authors' work based on http://maps.geoportal.gov.pl 
The areas examined in this paper, receive emissions from local industry and these are regarded to be primarily responsible for most of the trace elements in the air. Additionally, these areas are affected by heavy traffic and air-borne transboundary pollution from the Czech Republic. The accumulation of heavy metals in such an environment may cause chronic damage to living organisms and must be carefully controlled [7].

The following plant samples were taken: leaves of the common white birch Betula pendula, needles of the common larch Larix decidua, 2 years old needles of the Norway spruce Picea abies and the silver fir Abies alba as well as green parts of mosses: Pleurozium schreberi and the beautiful hair moss Polytrichum formosum. On each of the four objects 3-15 primary samples were taken, contributing to the mean sample. Samples were collected on the turn of September and October, in the minimal distance of $500 \mathrm{~m}$ from the roads and buildings. The exception made samples collected in the place called Aleje. In this case the distance from the road was about $2 \mathrm{~m}$. The trees were sampled on the breast height $(1.3 \mathrm{~m})$. The total number of mean samples was 21.

The collected material was first cleaned from contaminations. Then the parts of plants to be analyzed were separated (green gametophites of mosses, 2 years old needles of fir and spruce, needles of larch). The samples were dried in the drier in temperature of about $40^{\circ} \mathrm{C}$ and grinded in an electric grinder. From every sample $0.3 \mathrm{~g}$ of the material from a given s were taken and put in Teflon containers, where they were put into the mixture of acids ( $3 \mathrm{ml}$ of $35 \% \mathrm{HCL} 5 \mathrm{ml}$ of $65 \% \mathrm{HNO}_{3}$ ). Samples were mineralized in the microwave Speed Wave for 35 minutes (in temperature $200^{\circ} \mathrm{C}$ and at pressure of $40 \mathrm{bar}$ ), then cooling lasted 10 minutes. After the extraction, they were dissolved in $50 \mathrm{ml}$ of deionized water, filtered through hard paper filter and poured to sealed bottles. The content of trace metals: cadmium, copper and lead was determined by the method of flamed atomic absorption (FAAS) with spectrophotometer Hitachi Z-8200.

The compared groups were not numerous, so the Kruskal - Wallis test was applied, as based on ranks and allowing groups of different numbers. The significance level was $p=0.05$. Earlier the analysis of the normality of distribution was made (Kolmogorov-Smirnov Z test) and the homogeneity of variance (Levene's test). In case of failing to accept the hypothesis of the normality of distribution and homogeneity of variance a non-parametric Kruskal-Wallis test for the significance of differences, while post hoc comparisons were made by the Mann-Whitney U test.

\section{Results and Discussion}

The highest concentrations trace elements in the studied area was found in mosses: Pleurozium schreberi: $6.17-10.83 \mathrm{mg} / \mathrm{kg}$ d.w. $\mathrm{Cu} ; 0.6-2.37$ $\mathrm{mg} / \mathrm{kg}$ d.w. Cd; 7.0-27.7 mg/kg d.w. Pb and respectively: $8.33-10.83 \mathrm{mg} / \mathrm{kg}$ d.w.; 
0.6-0.72 mg/kg d.w.; 4.17-13.67 mg/kg d.w.in Polytrichum formosum. The needles of the Norway spruce Picea abies contain small contents of metals: $\mathrm{Cu}: 2.00-8.00 \mathrm{mg} / \mathrm{kg}$ d.w., Cd: $0.07-0.45 \mathrm{mg} / \mathrm{kg}$ d.w. and Pb: $0.17-3.83 \mathrm{mg} / \mathrm{kg} \mathrm{d.w}$. While the needles of the silver fir Abies alba accumulate: Cu: $2.85-19.50 \mathrm{mg} / \mathrm{kg}$ d.w., Cd: $0.22-1.30 \mathrm{mg} / \mathrm{kg}$ d.w. and $\mathrm{Pb}: 0.34-7.00 \mathrm{mg} / \mathrm{kg} \mathrm{d} . \mathrm{w}$. In the leaves of the common white birch Betula pendula $\mathrm{Cu}$ take the levels: $4.82-15.33 \mathrm{mg} / \mathrm{kg}$ d.w., Cd: $0.28-2.32 \mathrm{mg} / \mathrm{kg}$ d.w. and $\mathrm{Pb}: 1.33-5.41 \mathrm{mg} / \mathrm{kg}$ d.w. In the needles of the common larch Larix decidua there was: 4.82-44.17 mg/kg d.w. Cu; 0.35-0.45 mg/kg d.w. Cd and 1.00-8.50 mg/kg d.w. Pb (Tab. 1, Fig. 2).

The statistical analysis did not show significant differences in the content of $\mathrm{Cu}$ in the compared bioindicators. But in the case of $\mathrm{Cd}$ the result of the KruskalWallis turned out to be significant of the level of tendencji, $\chi^{2}-$ the variable of the chi-square distribution $=9.32 ; d f$ - the number of the degrees of freedom $=5 ; p-$ significance level $=0.097$. In moss tissues: Pleurozium schreberi and Polytrichum formosum there was a higher content of $\mathrm{Cd}$ than in the needles of the Norway spruce and in the needles of the common larch.

Table 1. Concentration of trace metals $[\mathrm{mg} / \mathrm{kg} \mathrm{d.w.]} \mathrm{in} \mathrm{plant} \mathrm{species}$

\begin{tabular}{|c|c|c|c|c|}
\hline \multirow{2}{*}{ Bioindicator } & \multirow{2}{*}{ Sampling site } & \multicolumn{3}{|c|}{$\begin{array}{l}\text { Concentration of trace metals } \\
\text { in bioindicators [mg } / \mathrm{kg} \text { d.w.] }\end{array}$} \\
\hline & & $\mathrm{Cu}$ & $\mathrm{Cd}$ & $\mathrm{Pb}$ \\
\hline \multirow{6}{*}{ Needles of the Norway spruce } & Aleje - Krakow & 8.00 & 0.07 & 3.17 \\
\hline & the Jurgowczyk Stream & 2.33 & 0.42 & 0.17 \\
\hline & the Sowiniec Range & 2.00 & 0.42 & 3.83 \\
\hline & the Silesian Beskid & 2.40 & 0.45 & 0.92 \\
\hline & mean & 3.68 & 0.34 & 2.02 \\
\hline & standard deviation SD & 2.58 & 0.18 & 1.75 \\
\hline \multirow{5}{*}{ Moss Pleurozium schreberi } & the Jurgowczyk Stream & 6.17 & 0.60 & 7.00 \\
\hline & the Sowiniec Range & 9.67 & 1.60 & 20.67 \\
\hline & the Silesian Beskid & 10.83 & 2.37 & 27.17 \\
\hline & mean & 8.89 & 1.52 & 18.28 \\
\hline & standard deviation SD & 2.43 & 0.89 & 10.30 \\
\hline
\end{tabular}




\begin{tabular}{|c|c|c|c|c|}
\hline \multirow{2}{*}{ Bioindicator } & \multirow{2}{*}{ Sampling site } & \multicolumn{3}{|c|}{$\begin{array}{l}\text { Concentration of trace metals } \\
\text { in bioindicators [mg } / \mathrm{kg} \text { d.w.] }\end{array}$} \\
\hline & & $\mathrm{Cu}$ & $\mathrm{Cd}$ & $\mathrm{Pb}$ \\
\hline \multirow{5}{*}{ Moss Polytrichum formosum } & the Jurgowczyk Stream & 8.33 & 0.63 & 4.17 \\
\hline & the Sowiniec Range & 10.00 & 0.72 & 9.00 \\
\hline & the Silesian Beskid & 10.83 & 0.60 & 13.67 \\
\hline & mean & 9.72 & 0.65 & 8.95 \\
\hline & standard deviation SD & 1.27 & 0.06 & 4.75 \\
\hline \multirow{5}{*}{ Needles of the common silver fir } & Aleje - Krakow & 19.50 & 0.22 & 7.00 \\
\hline & the Jurgowczyk Stream & 2.85 & 0.44 & 0.34 \\
\hline & the Silesian Beskid & 4.17 & 1.30 & 5.50 \\
\hline & average & 8.84 & 0.65 & 4.28 \\
\hline & standard deviation SD & 9.26 & 0.57 & 3.49 \\
\hline \multirow{6}{*}{ Leaves of the common white birch } & Aleje - Krakow & 15.33 & 0.28 & 4.00 \\
\hline & the Jurgowczyk Stream & 4.82 & 1.05 & 1.33 \\
\hline & the Sowiniec Range & 6.83 & 2.07 & 4.17 \\
\hline & the Silesian Beskid & 8.16 & 2.32 & 5.41 \\
\hline & mean & 8.76 & 1.43 & 3.73 \\
\hline & standard deviation SD & 4.57 & 0.94 & 1.72 \\
\hline \multirow{6}{*}{ Needles of the common larch } & Aleje - Krakow & 44.17 & 0.35 & 8.50 \\
\hline & the Jurgowczyk Stream & 4.83 & 0.40 & 1.00 \\
\hline & the Sowiniec Range & 4.82 & 0.45 & 3.99 \\
\hline & the Silesian Beskid & 6.83 & 0.42 & 4.00 \\
\hline & average & 15.16 & 0.41 & 4.37 \\
\hline & standard deviation SD & 19.36 & 0.04 & 3.09 \\
\hline
\end{tabular}



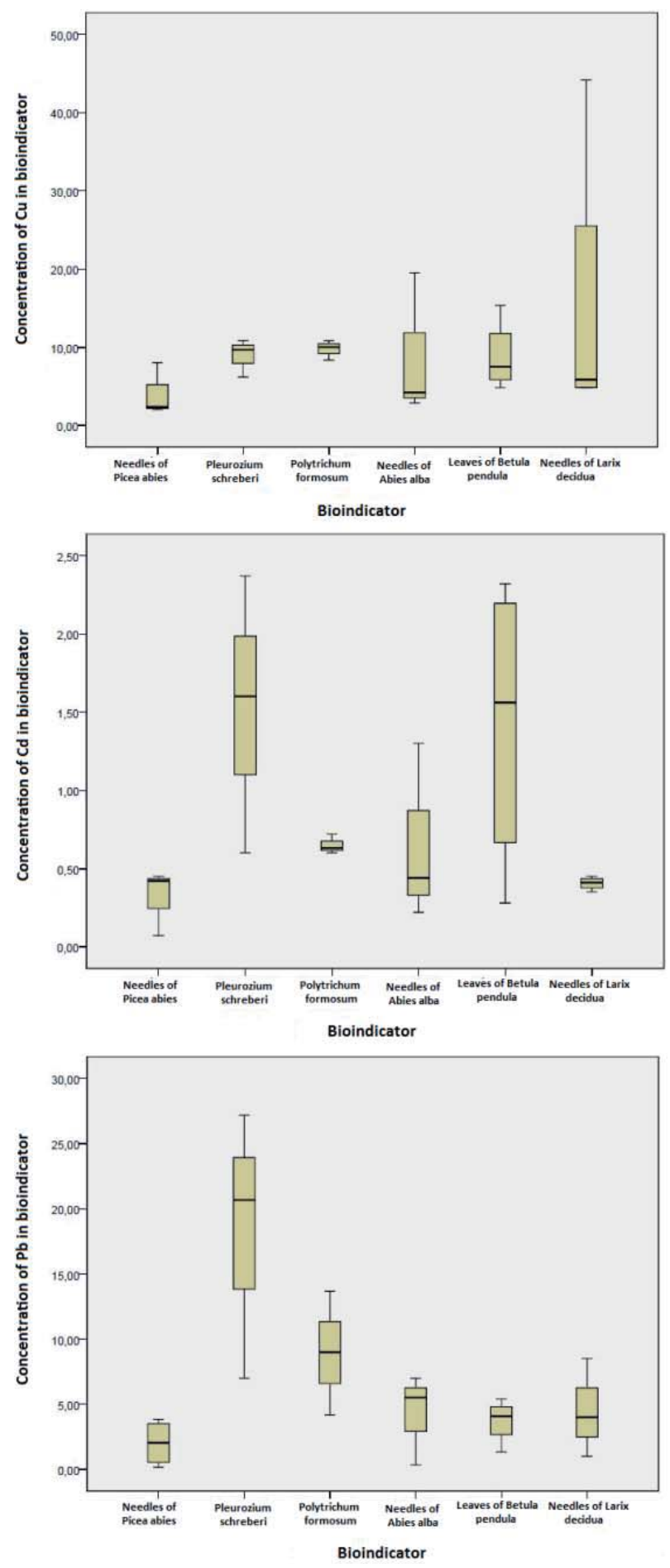

Fig. 2. Concentration of trace metals $[\mathrm{mg} / \mathrm{kg}$ d.w.] in plant species 
Statistically significant differences also occurred in the content of lead accumulated by the studied species: $\chi^{2}=12.00, d f=5, p<0.05$. The compared bioindicators show statistically significant differences in the content of $\mathrm{Pb}$. In the tissues of mosses Pleurozium schreberi and Polytrichum formosum the concentration of $\mathrm{Pb}$ is higher than in the needles of the Norway spruce. In five cases statistically significant differences were detected in the trends: in the leaves of the common white birch and common larch the $\mathrm{Pb}$ content is higher than in the needles of the Norway spruce. In the tissue of moss Pleurozium schreberi the $\mathrm{Pb}$ content is higher than in the needles of the common silver fir and common larch. In moss Polytrichum formosum there is more $\mathrm{Pb}$ than in the needles of the common larch.

The diminishing sequence of the copper concentration in the case of all the species of vascular plants is identical: Aleje > the Silesian Beskid > the Sowiniec Range >

the Jurgowczyk Stream. The highest content of cadmium was observed either in the Silesian Beskid or the range of Sowiniec, depending on the plant species. The lowest concentration of cadmium occurred in the Aleje Trzech Wieszczów in Krakow. The content of lead in the analyzed bioaccumulators in the respective area and objects, does not show such regularities. Generally, the highest $\mathrm{Pb}$ concentration, depending on the kind of the indicator occurred in the Aleje and the Silesian Beskid, the smallest amount of this element was found on the Spisz-Gubałów Foothills, and then in the Sowiniec Range.

\section{Conclusions}

The correctness of the indicator choice depends both on the object and metal, the concentration of which will be analyzed during the monitoring.

In the monitoring of copper pollution, all the analyzed plant species can be recommended, because they statistically do not differ in the ability to accumulate this element. The best bioindicators are mosses: Polytrichum formosum and Pleurozium schreberi (in particular in the less polluted areas). It can be stated that the poorest bioaccumulator of all the tested in this paper are the second year's of the Norway spruce Picea abies. Among the vascular plants: the leaves of the common white birch (Betula pendula) and needles of the common larch (Larix decidua) can turn out to be very helpful in the assessment of the environmental pollution with trace elements in the areas of high anthropopression, including traffic and in the areas, where it may be difficult to get mosses for the analysis. These species are common in Polski. Further studies are necessary to confirm and document more widely the statement that the studied vascular plants accumulate sufficient amount of trace metals, because the literature referring to these species, as phytoindicator are very scarce. In the existing publications on this topic, the content of heavy metals in the studied are show similar values to the concentrations given by other authors [5, 10, 11, 12, 15]. 


\section{References}

[1] Adriano D.C.: Trace Elements in Terrestrial Environments: Biogeochemistry, Bioavailability and Risks of Metals. 2nd Edition, Springer Verlag, New York, Berlin 2001.

[2] Čeburnis D., Steinnes E.: Conifer needles as biomonitors of atmospheric heavy metal deposition: comparison with mosses and precipitation, role of the canopy. Atmospheric Environment, no. 34, 2000, pp. 4265-4271.

[3] Conti M.: A statistical approach applied to trace metal data from biomonitoring studies. International Journal of Environmental and Pollution, no. 23, 2005, pp. 29-41.

[4] Fernandez J.A., Ederra A., Núñez E., Martínez-Abaigar J., Infante M., Heras P., Elías M.J, Mazimpaka V., Carballeira A.: Biomonitoring of metal deposition in northern Spain by moss analysis. Science of the Total Environment, no. 300, 2002, pp. 115-127.

[5] Gandois L., Probst A.: Localisation and mobility of trace metal in silver fir needles. Chemosphere, no. 87, 2012, pp. 204-210.

[6] Kabata-Pendias A., Pendias H.: Biogeochemia pierwiastków śladowych, Wyd. Nauk. PWN, Warszawa 1999.

[7] Kosior G., Samecka-Cymerman A., Kolon K., Kempers A.J.: Bioindication capacity of metal pollution of native and transplanted Pleurozium schreberi under various levels of pollution. Chemosphere, no. 81, 2010, pp. 321-326.

[8] Rühling Å.: A European survey of atmospheric heavy metal deposition in 20002001. Environmental Pollution, no. 120, 2002, pp. 23-25.

[9] Rühling Å., Tyler G.: Changes in atmospheric deposition rates of heavy metals in Sweden. Earth and Environmental Science, no. 1, 2001, pp. 311-323.

[10] Samecka-Cymerman A., Kolon K., Kempers A.J.: Short shoots of Betula pendula Roth. as bioindicators of urban environmental pollution in Wroctaw (Poland). Trees, no. 23, 2009, pp. 923-929.

[11] Sawidis T., Breuste J., Mitrovic M., Pavlovic P., Tsigaridas K.: Trees as bioindicator of heavy metal pollution in three European cities. Environmental Pollution, no. 159, 2011, pp. 3560-3570.

[12] Suchara I., Sucharova J., Hola M., Reimann C., Boyd R., Filzmoser P., Englmaier P.: The performance of moss, grass, and 1- and 2-year old spruce needles as bioindicators of contamination: A comparative study at the scale of the Czech Republic. Science of the Total Environment, no. 409, 2011, pp. 2281-2297.

[13] Szczepaniak K., Biziuk M.: Aspects of the biomonitoring studies using mosses and lichens as indicators of metal pollution. Environmental Research, no. 93, 2003, pp. 221-230. 
[14] Szyczewski P., Siepak J., Niedzielski P., Sobczyński T.: Research on Heavy Metals in Poland. Polish Journal of Environmental Studies, vol. 18, no. 5, 2009, pp. 755-768.

[15] Tomašević M., Aničić M., Jovanović Lj., Perić-Grujić A., Ristić M.: Deciduous tree leaves in trace elements biomonitoring: A contribution to methodology. Ecological Indicators, no. 11, 2001, pp. 1689-1695.

[16] Wappelhorst O., Kühn I., Oehlmann J., Markert B.: Deposition and disease: a moss monitoring project as an approach to ascertaining potential connections. The Science of the Total Environment, no. 249, 2000, pp. 243-256.

[17] Zechmeister H.G., Dirnböck T., Hülber K., Mirtl M.: Assessing airborne pollution effects on bryophytes - lessons learned through long-term integrated monitoring in Austria. Environmental Pollution, no. 147, 2007, pp. 696-705. 